\title{
Investigation of role magnetized water used in supplementary feeding for honeybees to modulate the genotoxic side effects induced by cyclophosphamide in mice bone marrow cells
}

\author{
Ekhlas. M. Farhan, ${ }^{a}$ Rukaibaa A. Chechan, ${ }^{\text {L Lina Q. Al-Kinanic }}$
}

¿Ministry of Sciences and Technology, Baghdad, Iraq.
'Deptartment of Food Science, College of Agriculture, University of Baghdad, Iraq.
'Deptartment of Plant protection, college of Agriculture, University of Karbala, Iraq.
Correspondence to: Ekhlas Mohammed Farhan (e-mail: sunlife88201@yahoo.com).
(Submitted:02 July 2017 - Revised version received: 19 July 2017 - Accepted: 22 September 2017 - Published online: 26 December 2017)

Objective To evaluate the possible protective role of honey formed through innovative way by using magnetized water instead of tab water in supplementary feeding for bees (HW) and compared with two honey types formed by two different feeding solutions; sugar syrup (HS) and nectar of flowers (HF) against cyclophosphamide (CP) genotoxicity in mice bone marrow cells, by using the micronucleus assay (MN). Methods Mice were divided into 8 groups from 3 animals each. G1 as control. G2 were exposed to CP (40 mg/kg), G3, G4, and G5 received two dose of three types of honey at doses $(300,600 \mathrm{mg} / \mathrm{kg}$ ) respectively. The other groups G6, G7 and G8 were supplemented with three types honey $(300 \mathrm{mg} / \mathrm{kg}$ ) in three different experimental protocols, as pre $2 \mathrm{~h}$, post $2 \mathrm{~h}$, and concomitant treatment for 7 and 14 days.

Results Examination and analysis of MN showed no mutagenic effect of three types honey per se doses, especially in low dose (300 mg/kg). Meanwhile, $C P$ induced a significant $(P<0.01)$ increase in MN frequency. While dual treatment with groups of honey HW caused a significant reduction in MN induced by CP in bone marrow cells in a time-dependant manner. Also, the results confirmed the protective efficacy of HW group and/or HF group as compared with HS group, against CP-toxicity.

Conclusion Our study suggests using magnetized water in supplementary feeding of bee, that could give the honey protective effect against genotoxicity induced by CP, it is also fosters antioxidant activity of honey constituents. Therefore, honey HW can be used as an adjuvant with chemotherapeutic agents for minimizing the genotoxic side effects of the anticancer drug CP.

Keywords genoprotective, supplementary feeding, magnetized water, cyclophosphamide (CP), micronucleus test

\section{Introduction}

In the rapidly changing lifestyles of our present times, the use of synthetic chemicals, chemotherapeutic agents, and carcinogenic substances, as well as the widespread environmental pollutants, have negatively impacted human and other living organisms at the cellular and genetic levels. Carcinogenic and mutagenic agents to which the human is continuously exposed leads to accumulation of free radicals in the body, compromising the ability of the biological system to remove toxins and repair the damage they cause, hence the oxidative phenomenon, which plays a major role in the development of many diseases. ${ }^{1,2}$ Natural products were known since the most ancient ages for their therapeutic values due to their varied chemical content, which helps preserve and develop selfdefense mechanisms, represented by the natural cellular resistance, which protects the cells from toxic products and other environmental stresses. Many studies have indicated the usability of naturally occurring chemical substances as effective antioxidants that improve human health and protect against cancer and heart diseases. ${ }^{3-4}$ It is noteworthy here that antioxidants are both anti-mutagenic, i.e., protect against potential nucleic acid damage and anti-carcinogenic, i.e., prevent the development of secondary tumors without interfering with the therapeutic action of chemotherapeutic agents. ${ }^{5,6}$ Since ancient times, natural honey has been widely used as a conventional medicine, scientific research has proven the therapeutic benefits of honey in treating several human diseases. Such as anti inflammatory, gastroprotective, antioxidant, antitumor and anticancer effects. ${ }^{7,8}$ Honey contains about 200 substances including fructose, glucose, amino acids, vitamins, minerals, water and enzymes. ${ }^{9}$ This protective effect of honey may be attributed to the biologically active compounds such as vitamins, flavonoids, and antioxidants that work together to scavenge free radicals. Composition of natural honey varies, depending on many factors such as the geographical areas, source of honeybee food, climate, environmental conditions..$^{10}$ Sidr honey is a "monofloral honey", a type of honey, that is made from bees who feed only on the nectar of the sidr tree, which has been used as a natural medicine for centuries. Sidr honey has strong antioxidant properties, and has wide medicinal applications and uses. ${ }^{11}$ Due to the absence of adequate natural food to provide winter food supplies, beekeepers use supplemental feeding of bees, mainly by sugar syrup, oftentimes, general water in supplementary feeding is used for dissolve the sugar. ${ }^{12}$ This present study throws light for the first time about used magnetized water instead of general water as an supplementary feeding. Water magnetization has been used for many years and was found that magnetization of water alters the properties of water. ${ }^{13}$ Several studies have demonstrated a lot of microscopic and macroscopic differences between magnetized water and normal water, which include the surface tension, contact angel, viscosity, electrical conductivity, $\mathrm{pH}$, etc. ${ }^{14}$ Raymond-Whish et al. ${ }^{15}$ reported the effect of commercial magnetic water conditioners on the total dissolved salts and $\mathrm{pH}$ on different solutions.

More hydroxyl $\left(\mathrm{OH}^{-}\right)$ions are created to form alkaline molecules, and reduce acidity, for this reason cancer cells do not survive well in an alkaline environment. ${ }^{16}$ Numerous animal studies have proved that electromagnetic fields have potential effects on cellular mechanism, development 
and growth especially in the reproductive system. ${ }^{17}$ Previously, it has been demonstrated that exposure to extremely low-frequency electromagnetic field (ELF-EMF) can increase height of fallopian tube epithelial cells. Although the exact mechanism of increasing epithelial cell height is not clear yet, it has been hypothesized that it could be due to increased permeability of cellular membrane to small molecules, especially $\mathrm{Ca}^{2+}$ current, free radical chemical reactions and increase in superoxide dismutase activity in the liver. ${ }^{18}$ Previous studies have investigated the effects of magnetized water on the height of endometrial epithelial cells, fallopian tube epithelium and the number of corpinstance it could decrease the amounts of malondialdehyde (MDA), increase the superoxide dismutase activity in the heart, kidney and liver and also decrease the amounts of nitric oxide which all result in decreasing oxidative stress. Therefore, it could be assumed that this potential reduction of oxidative stress will result in improving the reproductive system. ${ }^{15,19}$ Also, it has been demonstrated that intake of magnetized water will result in reduced DNA damage in STZ-induced diabetic rats. ${ }^{20}$ The other study showed that administration of magnetized water for at least 6 weeks suppressed the lymphocyte DNA damages in animals with diethyl nitrosamine (DEN)-induced cancer. ${ }^{21}$

\section{Material and Methods}

\section{Cyclophosphamide (CP) drug}

Cyclophosphamide (CP) was purchased from Sigma chemical Company (st. Louis, Mo, USA), $40 \mathrm{mg} / \mathrm{kg}$. b.w. of CP were dissolved in sterilized distilled water. Distilled water to prepare the required dose and concentration, which is equivalent to (1 mg CP/animal). Were used and injected intraperitoneally, according to method of Premkumar et al. ${ }^{22}$

\section{Feeding Colonies (Bees)}

Six colonies were selected as a container of bees belonging to the local L. Apismellifera L. The colonies were fed every three days and from $30 / 4$ to $15 / 6$

- The first group (3 colonies): colonies were feeding on dissolved sugar in magnetized water (water magnetizer/ CRYLOMAG MW) The sugar to water ratio in the groups (1:2) HW.

- The second group (3 colonies): The colonies fed by dissolved sugar in conventional water (tap water). The sugar to water ratio in the groups (1:2) (HS).

- Third group (3 colonies): feeding the bees naturally on the flowers of sidr trees. They are prescribed for the treatment of many diseases HF.

\section{Animals and Treatments}

The present study was carried out using mice at 12-9 weeks' age and 25-30 g, in weight which were purchased from National Center for Drug Control and Research/Ministry of Health/ Baghdad. They were housed in plastic cages containing hardwood chips, in the animal house laboratory in (Biotechnology Research Center), Al-Nahrain. The animals were given water and fed with a suitable quantity of water and complete diet.

Experience Design: The animals were divided into 14 groups

- Group 1: Negative control (3 mice) : Treated with (0.1 ml) PBS.
- Group 2: positive control (3 mice) the animals were treated with $0.2 \mathrm{ml} \mathrm{CP} 40 \mathrm{mg} / \mathrm{kg}$ for $24 \mathrm{hr}$

- Groups 3, 4 and 5: The animals were treated with two doses (300 and $600 \mathrm{mg} / \mathrm{kg}$ ) respectively, of each type of honey under study (9 mice).

- Pre-drug treatment with CP: The animals group (3 mice) were orally given $(0.5 \mathrm{ml}) \mathrm{HF}$ (Group 6), HW (Group 7) and HS (Group 8) respectively, per day for 7 and 14 days, before injected CP $(0.2 \mathrm{ml})$.

- Post-drug treatment with CP: The animals group (3 mice) were orally given $(0.2 \mathrm{ml}) \mathrm{CP}(40 \mathrm{mg} / \mathrm{kg})$ once (1 day), then followed by honeys (300 mg/kg b.w), HF (Group 9). HWr (Group 10), and HS (Group 11) respectively, per day for 7 and 14 days.

- Co-drug treatment with CP: The animals group (3 mice) were orally given $(0.2 \mathrm{ml}) \mathrm{CP}(40 \mathrm{mg} / \mathrm{kg})$ with $(0.5 \mathrm{ml})$ of honeys $(300 \mathrm{mg} / \mathrm{kg} \mathrm{b.w})$, HF (Group 12). HW (Group 13) and HS (Group 14) respectively, per day for 7 and 14 days.

\section{MN Assay}

The MN test was performed as previously described. ${ }^{23,24}$ The bone marrow $\mathrm{Mn}$ test is a well-known in vivo assay for the assessment of genotoxicity in animals such as mice and rats. All groups treated with CP had the drug injected intraperitoneally, ${ }^{25}$ while three type of honey was administered by Oral Intubation (O.I.) via an orogastric tube. ${ }^{26}$ Each group was treated daily for 7 and 14 consecutive days. ${ }^{27} 24$ hours after the last treatment. Both femurs were dissected and bone marrow was flushed from the femoral cavity with fetal calf serum. The cells were dispersed by gentle pipetting and collected by centrifugation at $1500 \mathrm{rpm}$ for $10 \mathrm{~min}$ the pellet was resuspended in a small volume of fetal calf serum and used for smear preparation. After air-drying, the smears were stained by Giemsa. ${ }^{28}$ From each animal, 1000 PCEs were examined for Mn-PCEs under 1000 magnification using light microscope. In addition, the number of PCEs among 500 total erythrocytes $(\mathrm{PCE}+\mathrm{NCE})$ per animal was recorded to evaluate bone marrow toxicity..$^{29,30}$

To calculate the protective (anti-mutagenic) rate of each honey against $\mathrm{CP}$ ) mutagenic effect, as reflected by induction of micronucleus formation the following equation was applied. $^{4,30}$

$$
\begin{array}{r}
100 \%(\mathrm{MN}) \text { in }(\mathrm{CP}+\text { honey }) \text { groups } \times 100 \%(\mathrm{MN}) \text { in } \\
(\mathrm{CP}) \text { groups }
\end{array}
$$

\section{Statistical Analysis}

The Statistical Analysis System-SAS (2012) program was used to effect of difference factors in study parameters. Least significant difference-LSD test (ANOVA) was used to significant compare between means in this study. ${ }^{31}$

\section{Results and Discussion}

This study aimed at evaluating the potential genetic, cellular, and preventive impact of treatment with three type of honey per se, combined, precedent, simultaneous, and subsequent treatment with three types of honey for 7 and 14 consecutive days. and CP and treatment with CP per se. Results of the micronuclear test showed a highly significant ability of $\mathrm{CP}$ (positive control) to produce $\mathrm{MN}, 10.03 \pm 1.04$ in 
bone marrow cells of mice, corresponding controls (negative control), $1.12 \pm 0.07$ as shown in Fig. 1, Table 1. This is consistent with results arrived at by many previous researchers, who treated bone marrow cells using members of the group of alkylating anticancer drugs of which the drug under study CP, is also a member. ${ }^{22,32,33}$ Micronuclei originate from acentric chromatid or chromosomal splinters or from whole chromosomes that do not join the nucleus proper at the end of the final phase of cell division (telophase), due to a failure of proper connection to spindle fibers during the anaphase of cell division. These chromosomes or chromosomal splinters are joined together by means of a nuclear membrane and are small in size, compared with the size of the nucleus proper. ${ }^{1}$ Micronuclei form as a result of treatment with antineoplastic drugs that either cause direct damage to the nucleic acid or inhibit the cell cycle or damage the spindle fibers of mitotic division..$^{34}$ The micronuclear test being the most sensitive and the most powerful statistical tool to evaluate DNA breaks, which indicate potential mutations. ${ }^{35}$ Meanwhile, Results showed that three types of honey, which used in this study formed by different feed sources (HS, HW and HF, had no significant effect on the induction of micronuclei in bone marrow cells, which showed nearly the same values of control as shown in Table 1 . Significantly $(P<0.01)$ as compared with negative control, especially in the low dose, although, the high dose $(600 \mathrm{mg} / \mathrm{kg})$ of honey (HS) showed significant differences $(P<0.01)$ of frequencies micronuclei as compared with negative control, but no statistically significant in micronucleus in comparison with positive group.

\begin{tabular}{|c|c|c|}
\hline Experimental groups & Dose (mg/kg) & Micronuclei (MN)\% \\
\hline Negative control & 0 & $1.12 \pm 0.07 c$ \\
\hline Positive control (CP Only) & 40 & $10.03 \pm 1.04^{\mathrm{a}}$ \\
\hline \multirow{2}{*}{$\begin{array}{l}\text { Honey formed by (floral } \\
\text { resources) HF }\end{array}$} & 300 & $1.67 \pm 0.08^{c}$ \\
\hline & 600 & $2.15 \pm 0.08^{c}$ \\
\hline \multirow{2}{*}{$\begin{array}{l}\text { Honey formed by - sugar } \\
\text { syrup (HS) }\end{array}$} & 300 & $3.90 \pm 0.11^{b c}$ \\
\hline & 600 & $4.76 \pm 0.17^{b}$ \\
\hline \multirow{2}{*}{$\begin{array}{l}\text { Honey formed by - (sugar } \\
\text { with magnetized water) (HW) }\end{array}$} & 300 & $1.18 \pm 0.04^{c}$ \\
\hline & 600 & $2.32 \pm 0.08^{c}$ \\
\hline P-value & - & $0.00026^{* *}$ \\
\hline
\end{tabular}

Means having with the different letters in same column differed significantly.

$* *(P<0.01)$. Differences $a, b, c$ and $d$, are Significant $(P \leq 0.01)$ to Comparison Rows.
Micronucleus test is good evidence of cytogenetic toxicity, and features a quick and simple test short-term test for this evaluation as it is inexpensive. ${ }^{36}$ It is clear that the emergence of micronucleus in the cells (PECs) in mice treated with CP, obtained from the current study is strong evidence on the impact of toxic cellular genetic property and an indicator of its ability mutagens. ${ }^{37}$ As noted also that treatment with HF combine, precedent, simultaneous, and subsequent, treatment with $\mathrm{HF}$ and $\mathrm{CP}$, caused a highly significant reduction in the numbers of micronuclei in micronucleated polychromatic erythrocytes (MN-PCEs) by $2.80 \pm 0.08,4.46 \pm 0.15$ and $2.35 \pm 0.08$, for 7 day respectively, However, the numbers of micronuclei decreased significantly $(P<0.01)$ by $1.76 \pm 0.02,2.15 \pm 0.05$ and $1.68 \pm 0.03$, for 14 days respectively, as compared with the positive control $9.26 \pm 0.62$ (Table 2). This result is consistent with findings of previous studies that suggested the possibility of prevention of genotoxic effects resulting from chemotherapy, by using HF. ${ }^{37,38}$ Several explanations have been offered for anti-mutagenic activity of honey, the mechanisms of the protective of honey against CP genotoxicity may be due to one or more of the following: antioxidant action ${ }^{39,40}$ and to stimulate the antioxidative enzyme glutathione peroxidas, ${ }^{41}$ leading to an increase in antioxidant capacity of the cells which might fortify the efficiency of protective pathways against cytogenetic damage in CP exposure, ${ }^{42}$ therefore, it has been used as a compared group with other types of honey's used in this investigation. it is clear that there were high significant differences in frequencies of $\mathrm{MN}$ between the groups which treated with both honey formed by supplementary feeding (HS and/or HW) respectively, in three interactions used (before, after, with treatment) (Tables 3 and 4). Furthermore; it has been shown that HW achievement best efficacy in a reduction frequencies of micronucleus significantly $(P<0.01)$ by $3.12 \pm 0.07,3.32 \pm 0.07$ and $1.63 \pm 0.03$ for 7 day respectively, the numbers of micronuclei decreased significantly $(P<0.01)$ by $1.42 \pm 0.3,2.02 \pm 0.06$ and $0.87 \pm 0.02$, for 14 days respectively, as compared with the corresponding controls $10.08 \pm 0.52$ (Table 4). Furthermore, the data obtained when treatment with HS was $6.47 \pm 0.37$, $7.13 \pm 0.28$ and $5.75 \pm 0.22$ for 7 days respectively, the numbers of micronuclei increased significantly $(P<0.01)$ by $7.39 \pm 0.36$, $8.25 \pm 0.51$ and $7.15 \pm 0.33$ for 14 days respectively, as compared with the corresponding controls $10.12 \pm 0.72$, Table 3 . The results of honey HW came similar with the results of comparison group (honey HF) and was more effective than HS, at any treatment or at any time intervals used. And the fact that this is the first study in the world, which throws light of cytogenetic effect of honey formed by supplementary feeding, therefore, no literature available for the purpose of comparing
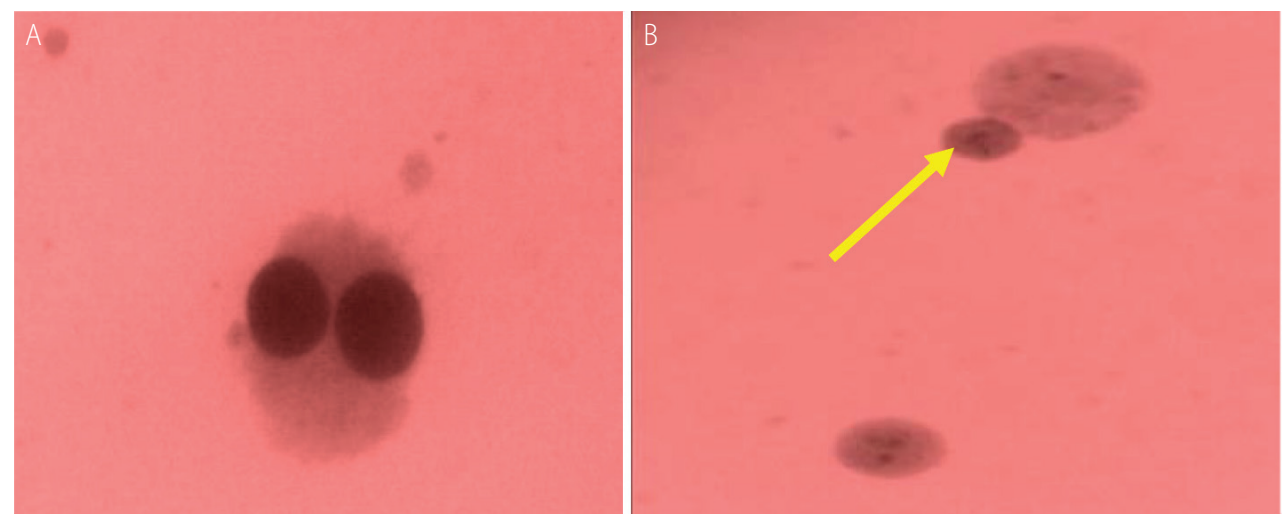

Fig. 1 Giemsa-stained binucleated in bone marrow cells of mice treated with cyclophosphamide (CP) A: polychromatic erythrocytes "normal"; B: polychromatic erythrocytes with "micronucleus" (X1000). 


\begin{tabular}{|c|c|c|c|c|c|}
\hline \multicolumn{2}{|c|}{ Groups treatment } & Dose mg/kg & $\begin{array}{l}\text { The calculated number of } \\
\text { polychromatic erythrocytes }\end{array}$ & Total no. of MN\% & $\begin{array}{c}\text { The rate of antimutagens } \\
\text { effects }\end{array}$ \\
\hline \multicolumn{2}{|c|}{ Negative control } & 0.00 & 1000 & $1.45 \pm 0.07 c$ & - \\
\hline \multicolumn{2}{|c|}{ Positive control treated with CP only } & 40 & 1000 & $9.26 \pm 0.62^{\mathrm{a}}$ & - \\
\hline \multirow{4}{*}{7 day } & Honey (HF) & 300 & 1000 & $1.67 \pm 0.04^{c}$ & - \\
\hline & Pre-Honey (HF) & & 1000 & $2.80 \pm 0.08 b^{c}$ & 69 \\
\hline & Post-Honey (HF) & & 1000 & $4.46 \pm 0.15^{b}$ & 54 \\
\hline & Co-treatment Honey (HF) + CP & & 1000 & $2.35 \pm 0.08^{\mathrm{bc}}$ & 76 \\
\hline \multicolumn{2}{|c|}{$P$-value } & - & - & $0.0001^{* *}$ & - \\
\hline \multicolumn{2}{|c|}{ Negative control } & 0.00 & 1000 & $1.45 \pm 0.07^{b}$ & - \\
\hline \multicolumn{2}{|c|}{ Positive control treated with CP only } & 40 & 1000 & $9.26 \pm 0.62^{\mathrm{a}}$ & - \\
\hline \multirow{3}{*}{14 day } & Honey (HF) & 300 & 1000 & $1.32 \pm 0.02^{b}$ & - \\
\hline & Pre-Honey (HF) & & 1000 & $1.76 \pm 0.02^{b}$ & 80 \\
\hline & Post-Honey (HF) & & 1000 & $2.15 \pm 0.05^{b}$ & 78 \\
\hline & Co-treatment Honey $(\mathrm{HF})+\mathrm{CP}$ & & 1000 & $1.68 \pm 0.03^{b}$ & 83 \\
\hline \multicolumn{2}{|c|}{$P$-value } & - & - & $0.0001^{* *}$ & - \\
\hline
\end{tabular}

Means having with the different letters in same column differed significantly. ${ }^{* *}(P<0.01)$. Differences $a, b, c$ and $d$, are Significant $(P \leq 0.01)$ to Comparison Rows.

\begin{tabular}{|c|c|c|c|c|c|}
\hline \multicolumn{2}{|c|}{ Groups treatment } & Dose mg/kg & $\begin{array}{l}\text { The calculated number of } \\
\text { polychromatic erythrocytes }\end{array}$ & Total no. of MN\% & $\begin{array}{c}\text { The rate of } \\
\text { antimutagens effects }\end{array}$ \\
\hline \multicolumn{2}{|c|}{ Negative control } & 0.00 & 1000 & $1.64 \pm 0.08^{d}$ & - \\
\hline \multicolumn{2}{|c|}{ Positive control treated with CP only } & 40 & 1000 & $10.12 \pm 0.72^{\mathrm{a}}$ & - \\
\hline \multirow{4}{*}{7 day } & Honey (HS) & 300 & 1000 & $3.90 \pm 0.13^{\mathrm{cd}}$ & - \\
\hline & Pre-Honey (HS) & & 1000 & $6.47 \pm 0.37^{b}$ & 42 \\
\hline & Post-Honey ( HS) & & 1000 & $7.13 \pm 0.28^{b}$ & 29 \\
\hline & Co-treatment Honey $(\mathrm{HS})+\mathrm{CP}$ & & 1000 & $5.75 \pm 0.22^{b c}$ & 45 \\
\hline \multicolumn{2}{|l|}{$P$-value } & - & - & $0.0001^{* *}$ & - \\
\hline \multicolumn{2}{|c|}{ Negative control } & 0.00 & 1000 & $1.64 \pm 0.08^{c}$ & - \\
\hline \multicolumn{2}{|c|}{ Positive control treated with CP only } & 40 & 1000 & $10.12 \pm 0.72^{\mathrm{a}}$ & - \\
\hline \multirow{4}{*}{14 day } & Honey (HS) & 300 & 1000 & $3.90 \pm 0.13^{c}$ & - \\
\hline & Pre-Honey (HS) & & 1000 & $7.39 \pm 0.36^{b}$ & 34 \\
\hline & Post-Honey (HS) & & 1000 & $8.25 \pm 0.51^{\mathrm{ab}}$ & 18 \\
\hline & Co-treatment Honey $(\mathrm{HS})+\mathrm{CP}$ & & 1000 & $7.15 \pm 0.33^{b}$ & 31 \\
\hline \multicolumn{2}{|l|}{$P$-value } & - & - & $0.0001^{* *}$ & - \\
\hline
\end{tabular}

Means having with the different letters in same column differed significantly. ${ }^{* *}(P<0.01)$. Differences $a, b, c$ and $d$, are Significant $(P \leq 0.01)$ to Comparison Rows.

results. May be attributed that the magnetized water could influence effectively on the oxidant-antioxidant balance, for instance, it could decrease the amounts of malondialdehyde (MDA), increase the superoxide dismutase activity in the heart, kidney and liver and also decrease the amounts of nitric oxide which all result in decreasing oxidative stress. ${ }^{18,19}$ Can ameliorate the deleterious effect of free radicals by decreasing the chemical reactions that caused damage to DNA, proteins and lipids. Water magnetization changes water properties which becomes more energized, active, soft and high $\mathrm{pH}$ toward slight alkaline and free of germs ${ }^{43}$ also Al-Mufarrej et al. ${ }^{44}$ mentioned that, water solution increases the fluidity, dissolving capability for various constituents like minerals and vitamins and consequently improves the biological activity of solutions, affecting positively the performance of animals and plants. Physics shows that water changes its weight under the influence of magnetic fields. More hydroxyl $\left(\mathrm{OH}^{-}\right)$ions are created to form alkaline molecules, and reduce acidity, for this reason cancer cells do not survive well in an alkaline environment. ${ }^{45}$ Some animal studies have concluded that the magnetization of water increased the permeability through cell membranes, ${ }^{46}$ and that the magnetic field directly affected intracellular fluid and intracellular substances to activate enzymes inside the cells and to accelerate biochemical reactions in the body. ${ }^{47}$ Previous studies with magnetized water, reported that the long-term intake of magnetized water (over 8 weeks) may be beneficial in both prevention and treatment of complications in diabetic, treatment effect of magnetized water not only decreased the blood 


\begin{tabular}{|c|c|c|c|c|c|}
\hline \multicolumn{2}{|c|}{ Groups treatment } & Dose mg/kg & $\begin{array}{l}\text { The calculated number of } \\
\text { polychromatic erythrocytes }\end{array}$ & Total no. of MN \% & $\begin{array}{l}\text { The rate of antimutagens } \\
\text { effects }\end{array}$ \\
\hline \multicolumn{2}{|c|}{ Negative control } & 0.00 & 1000 & $0.78 \pm 0.06^{c}$ & - \\
\hline \multicolumn{2}{|c|}{ Positive control treated with CP only } & 40 & 1000 & $10.08 \pm 0.52^{a}$ & - \\
\hline \multirow{4}{*}{7 day } & Honey (HW) & 300 & 1000 & $1.18 \pm 0.03^{c}$ & - \\
\hline & Pre-Honey (HW) & & 1000 & $3.12 \pm 0.07^{b}$ & 69 \\
\hline & Post-Honey (HW) & & 1000 & $3.32 \pm 0.07^{b}$ & 67 \\
\hline & Co-treatment Honey $(\mathrm{HW})+\mathrm{CP}$ & & 1000 & $1.63 \pm 0.03^{c}$ & 85 \\
\hline \multicolumn{2}{|c|}{$P$-value } & - & - & 0.0001 & - \\
\hline \multicolumn{2}{|c|}{ Negative control } & 0.00 & 1000 & $0.78 \pm 0.06^{c}$ & - \\
\hline \multicolumn{2}{|c|}{ Positive control treated with CP only } & 40 & 1000 & $10.08 \pm 0.52^{a}$ & - \\
\hline \multirow{4}{*}{14 day } & Honey (HW) & 300 & 1000 & $1.18 \pm 0.03^{b c}$ & - \\
\hline & Pre-Honey (HW) & & 1000 & $1.42 \pm 0.3^{b c}$ & 85 \\
\hline & Post-Honey (HW) & & 1000 & $2.02 \pm 0.06^{b}$ & 80 \\
\hline & Co-treatment Honey $(\mathrm{HW})+\mathrm{CP}$ & & 1000 & $0.87 \pm 0.02^{c}$ & 92 \\
\hline \multicolumn{2}{|c|}{$P$-value } & - & - & $0.0001^{* *}$ & - \\
\hline
\end{tabular}

Means having with the different letters in same column differed significantly. ${ }^{* *}(P<0.01)$. Differences $a, b, c$ and $d$, are Significant $(P \leq 0.01)$ to Comparison Rows.

glucose and glycated hemoglobin levels but also reduced blood and liver DNA damages in STZ-induced diabetic rats. ${ }^{20} \mathrm{Ma}$ et al. $^{48}$ presented the possibility that magnetic water can prevent aging and fatigue by increasing the cell membrane permeability. Also, the other study showed that administration of magnetized water for at least 6 weeks suppressed the lymphocyte DNA damages in animals with DEN)-induced cancer. ${ }^{21}$

\section{Conclusion}

In conclusion, the present study demonstrated dangerous effect of anticancer drug CP could be avoided by using the treatment of honey formed by the innovative way (sugar with magnetized water). Additionally, our results indicate the use magnetized water in honey formation may be beneficial to increase efficacy honey for modulating the genotoxicity induced by $\mathrm{CP}$ in mice, diminishing the deleterious side effects of anticancer drug with preservation of its chemotherapeutic efficacy. This is the first study in the world, No literature available for using the magnetic water to attract honey bees for the purpose of honey formation. Therefore, further studies are required to confirm these results, especially about using the magnetized water in the formation of honey and to investigate the possible mechanism from honey (HW) responsible for such effect. The present study, therefore, recommends further studies that show the relationship between used magnetized water on supplementary feeding and the stimulation of these antioxidants in the body and its ability to reduce the toxic effects of cancer drugs.

\section{References}

1. Fenech M, Kirsch-Volders M, Natarajan AT, Surralles J, Crott JW, Parry J, et al. Molecular mechanisms of micronucleus, nucleoplasmic bridge and nuclear bud formation in mammalian and human cells. Mutagenesis. 2011;26: 125-132.

2. Mena S, Ortega A, Estrela JM. Oxidative stress in environmental-induced carcinogenesis. Mutat Res. 2009;674:36-44

3. Kumar R, Kumar T, Kamboj V, Chander H. Pharmacological evaluation of ethanolic extract of kigelia pinnata fruit against ethylene glycol induced urolithiasis in rats. Asian J Plant Sci Res. 2012;2:63-72.

4. Ekhlas Mohammed F, Al-Taai. Protective effects of sweet orange peel (Citrus Sinensis L.) The induction of micronuclei induced by cyclophosphamide in human peripheral lymphocytes. J Food Technol Res. 2016;3:28-35

5. Lina Abdul-FK, Fatimah AA. Reduction of Dacarbazine cytogenetic effects on somatic cells in male mice using bee glue (Propolis) to manifest the scientific miracles in the Quran. Electron Physician. 2016;8:3015-3023.

6. Shen DW, Pouliot LM, Hall MD, Gottesman MM. Cisplatin resistance: a cellular self-defense mechanism resulting from multiple epigenetic and genetic changes. Pharmacol Rev. 2012;64:706-721.

7. Ahmed S, Othman NH. Honey as a potential natural anticancer agent: a review of its mechanisms. Evid Based Complement Alternat Med. 2013;2013:829070.

8. Erejuwa OO, Sulaiman SA, Wahab MS. Effects of honey and its mechanisms of action on the development and progression of cancer. Molecules. 2014;19:2497-2522

9. Chechan RA. Separation of monosaccharides (glucose and fructose) from Date juice by crystallization. Thesis, college of Agriculture Baghdad university. 2001.

10. Aljadi AM, Kamaruddin MY. Evaluation of the phenolic contents and antioxidant capacities of two Malaysian floral honeys. Food Chem. 2004;85:513-518

11. Abdel-Latif MM. Chemoprevention of gastrointestinal cancers by natural honey. World J Pharmacol. 2015;4:160-167.

12. Dustmann JH, Wehling MW, Von der Ohe. Conversion of specific sugar solutions after their intake by honeybees", The XXXV"th Int. Apicultural Congress of Apimondia, Antwerpen, 354, 1997.

13. Hafizi L, Gholizadeh M, Karimi M, Hosseini G, Mostafavi-Toroghi H, Haddadi M, et al. Effects of magnetized water on ovary, pre-implantation stage endometrial and fallopian tube epithelial cells in mice. Iran J Reprod Med. 2014.

14. Sueda M, Katsuki A, Nonomura M, Kobayashi R, Tanimoto Y. Effects of high magnetic field on water surface phenomena. J Phys Chem. 2007;111:14389-14393.

15. Verma SS. Magnetic water treatment. Chem Business J. 2011;13-16.

16. Iorio R, Delle Monache S, Bennato F, Di Bartolomeo C, Scrimaglio R, Cinque $B$, et al. Involvement of mitochondrial activity in mediating ELF- 
EMF stimulatory effect on human sperm motility. Bioelectromagnetics. 2011;32:15-27.

17. Gholizadeh M, Arabshahi H, Saeidi MR, Mahdavi B. The Effect of Magnetic Water on Growth and Quality Improvement of Poultry. Middle-East I Sci Res. 2008:3:140-144

18. Wang $D$, Cheng $X$, Yan $X$. Effect of magnetized liquor on free radical metabolism in the heart of mice. Chinese J Med Phys. 2002;19:243-244

19. Raymond-Whish S, Mayer LP, O'Neal T, Martinez A, Sellers MA, Christian PJ, et al. Drinking water with uranium below the U.S. EPA water standard causes estrogen receptor-dependent responses in female mice. Environ Health Perspect. 2007:115:1711-1716.

20. Lee $H J$, Kang MH. Effect of the magnetized water supplementation on blood glucose, lymphocyte DNA damage, antioxidant status, and lipid profiles in STZ induced rats. Nutr Res Pract. 2013;7:34-42.

21. Lee HJ, Jo HR, Jeon EJ, Kang MH. Effect of the magnetized water supplementation on lymphocyte DNA damage in mice treated with diethylnitrosamine. Korean J Nutr. 2010;43:570-577.

22. Premkumar K, Kavitha S, Santhiya ST, Ramesh AR. Interactive effects of saffron with garlic and curcumin against Cyclophosphamide induced genotoxicity in mice. Asia Pac J Clin Nutr. 2004;13:292-294.

23. Ahmadi A, Hosseinimehr SJ, Naghshvar F, Hajir E, Ghahremani M. Chemoprotective effects of hesperidin againstgenotoxicity induced by cyclophosphamide in mice bone marrowcells. Arch Pharm Res. 2008;31:794-797.

24. Hosseinimehr SJ, Ahmadashrafi S, Naghshvar F, Ahmadi A, Ehasnalavi, Tanha M. Chemoprotective effects of zataria multiflora against genotoxicity induced by cyclophosphamide in mice bone marrow cells. Integrat Cancer Therap. 2010:9:219-223.

25. Anton E. Ultrastructural changes of stromal cells of bone marrow and liver after cyclophosphamide treatment in mice. Tissue Cell. 1997:29:1-9.

26. Sakr SA, Zoil MS, El-Shafey SS. Ameliorative effect of grapefruit juice on amiodarone-induced cytogenetic and testicular damage in albino rats. Asian Pac J Trop Biomed. 2013;3:573-579.

27. Eroğlu HE. The cytogenetic effects of black tea and green tea on cultured human lymphocytes. Braz Arch Biol Technol. 2011;54:1159-1165.

28. Schmid W. Chemical mutagen testing on in vivo somatic mammalian cells. Agents Actions. 1973;3:77-85.

29. Naghshvar F, Abianeh SM, Ahmadashrafi S, Hosseinimehr SJ. Chemoprotective effects of carnosine against genotoxicity induced by cyclophosphamide in mice bone marrow cells. Cell Biochem Funct. 2012;30:569-573.

30. Serpeloni JM, Bisarro dos Reis M, Rodrigues J, Campaner dos Santos L, Vilegas W, Varanda EA, et al. In vivo assessment of DNA damage and protective effects of extracts from Miconia species using the comet assay and micronucleus test. Mutagenesis. 2008;23:501-507.

31. SAS. Statistical analysis system, user's guide. Statistical. Version $9.1^{\text {th }}$ ed. SAS. Inst. Inc. Cary. N.C. USA. 2012.

32. Vijayalaxmi KK, D'Souza MP. Studies on the genotoxic effects of anticancer drug carboplatin in vivo mouse. Int J Hum Genet. 2004;4:249-255.
33. Asita AO, Molise T. Antimutageic effects of red apple and watermelon juices on cyclophosphamide-induced genotoxicity in mice. African Journal of Biotechnology. 2011;10:17763-17768.

34. Samanta S, Dey P. Micronucleus and its applications. Diagn Cytopathol. 2012:40:84-90

35. Araldi RP, de Melo TC, Mendes TB, de Sá Júnior PL, Nozima BH, Ito ET, et al. Using the comet and micronucleus assays for genotoxicity studies: a review. Biomed Pharmacother. 2015;72:74-82.

36. Kirsch-Volders M, Vanhauwaert A, Eichenlaub-Ritter U, Decordier I. Indirect mechanisms of genotoxicity. Toxicol Lett. 2003;140-141.

37. El-Fiky SA, Farag IM, Zoheir KMA, Hassan NHA, Elalfy HGM. The protective role of honey-bee products against the genotoxic effects of cyclophosphamide in male mice. J Appl Sci Res. 2013:9:4745-4758.

38. Shahrour A, Zowail M, Sharafeldin K. The protective role of honey against cytotoxicity of cadmium chloride in mice. Afr J Biotechnol. 2016;15: 2620-2626.

39. Silva TMS, Santos FP, Evangelista-Rodrigues A, et al. Phenolic compounds, melissopalynological, physicochemical analysis and antioxidant activity of jandaı'ra (Melipona subnitida) honey. J Food Comp Anal. 2013;29:10-18.

40. El Sohaimy SA, Masry SHD, Shehata MG. Physicochemical characteristics of honey from different origins. Ann Agricult Sci. 2015:60:279-287.

41. Tomás-Zapico C, Coto-Montes A. A proposed mechanism to explain the stimulatory effect of melatonin on antioxidative enzymes. J Pineal Res. 2005:39:99-104

42. Ustundag A, Duydu Y. The influence of melatonin and Nacetylcysteine in delta-aminolevulinic acid and lead induced genotoxicity in lymphocytes in vitro. Biol Trace Elem Res. 2007;117:53-64.

43. Rajaei F, Borhani N, Sabbagh-Ziarani F, Mashayekhi F. Effects of extremely low-frequency electromagnetic field on fertility and heights of epithelia cells in pre-implantation stage endometrium and fallopian tube in mice. Zhong Xi Yi Jie He Xue Bao. 2010;8:56-60.

44. Al-Mufarrej S, Al-Batshan HA, Shalaby MI, Shafey TM. The effects of magnetically treated water on the performance and immune system of broiler chickens. Inte J Poul Sci. 2005;4:96-102.

45. Park KS, Kim JH, Kim MS, Kim JM, Kim SK, Choi JY, et al. Effects of insulin and antioxidant on plasma 8-hydroxyguanine and tissue 8-hydroxydeoxyguanosine in streptozotocin-induced diabetic rats. Diabetes. 2001;50 2837-2841.

46. Lednev V. Possible mechanism for the influence of weak magnetic fields on biological systems. Bioelectromagnetics. 1991;12:71-75.

47. Liboff AR, Cherng S, Jenrow KA, Bull A. Calmodulin-dependent cyclic nucleotide phosphodiesterase activity is altered by $20 \mu \mathrm{T}$ magnetostatic fields. Bioelectromagnetics. 2003;24:32-38.

48. Ma YL, Ren H, Ren S, Zhen EK, Hao G, Zhao YW. A study of the effect of magnetized water on enzyme activities by potentiometric enzyme electrode method. J Tongji Med Univ. 1992;12:193. 